\title{
INFORMACIÓN AUTORES
}

\section{Normas para el envío de originales}

1. Temas de interés. La Revista de Historia Económica. Journal of Iberian and Latin American Economic History publica artículos de investigación sobre historia económica, historia del pensamiento económico y todos aquellos campos de la economía relacionados con el análisis del largo plazo. El ámbito geográfico de sus artículos lo constituyen, preferentemente, la Península Ibérica e Iberoamérica, así como aquellas áreas, más amplias, que engloban a las anteriores. Los trabajos que se envíen a la Revista han de ser originales, no publicados ni sometidos a consideración para su publicación en otra parte.

2. Proceso de evaluación y tiempos de publicación. Los editores se proponen ser rigurosos y transparentes en el proceso de revisión haciendo explícito el protocolo de evaluación desde el acuse de recibo hasta la aceptación final (ver Proceso de Revisión en la página web). Así como razonablemente expeditivos entre la recepción de la versión final del manuscrito, con la incorporación de las revisiones requeridas para la aceptación, y la publicación final que llevará entre dos y tres números (es decir entre ocho y doce meses).

3. Envío. Los originales se enviarán en español, inglés o portugués, escritos en Microsoft Word. Se enviarán preferentemente por correo electrónico a la dirección rhe-jilaeh@uc3m.es; excepcionalmente, se podrán enviar también en papel (una copia), junto con un archivo en disquete o CD ROM, a nombre del Director responsable de la Revista y a las señas siguientes:

Prof. Antonio Tena (antonio.tena@uc3m.es).

Departamento de Historia Económica.

Universidad Carlos III de Madrid.

C/ Madrid, 126

E-28903 Getafe (España).

RHE-JILAEH acusará recibo de todos los originales en un plazo no superior a diez días desde su recepción.

4. Formato. Los originales deberán ir escritos a doble espacio, en letra Times New Roman tamaño 12. La extensión total no superará las 30 páginas (10.000 a 12.000 palabras), incluidos gráficos, cuadros, notas a pie de página, bibliografía y apéndices en su caso. La primera página incluirá el título, nombre del autor o autores, filiación académica, dirección tanto de correo ordinario como de correo electrónico, y número(s) de teléfono. En una segunda página se presentarán dos resúmenes, en español (portugués) e inglés, de unas 120 palabras cada uno, entre tres y cinco palabras clave (en los dos idiomas) y la(s) clasificación(es) JEL. Con el fin de garantizar el anonimato en el proceso de evaluación, el resto del texto no podrá incluir ninguna mención al autor o autores (incluidas las que se hagan en notas a pie de página) que permita desvelar su identidad. Los originales observarán el siguiente orden: texto con sus notas a pie de página, seguido por apéndices y bibliografía. En la medida de lo posible, los cuadros, gráficos y mapas se insertarán en sus lugares dentro del texto, con el mismo tipo de letra que éste y a tamaño similar; cuando no, deberán ir incluidos al final del texto, o en un archivo separado. Todas las páginas habrán de ir numeradas correlativamente. La notas, debates y ensayos bibliográficos no deberán superar las 10 páginas (3.300-4.000 palabras) 


\section{Normas de edición:}

a. Bibliografía. Las referencias bibliográficas irán ordenadas alfabéticamente por el apellido (en mayúsculas) del autor, bajo el título «Bibliografía» y al final del original. Si se citan dos o más obras de un determinado autor publicadas en el mismo año, éstas se distinguirán por medio de una letra. Ejemplo: Clark (2004a) y Clark (2004b). Las referencias se limitarán a obras citadas en el trabajo. Como ejemplos, se incluyen los siguientes:

MARTÍN ACEÑA, P., y PONS, M. ${ }^{a}$ A. (2005): «El sistema monetario y financiero», en A. Carreras y X. Tafunell (coords.), Estadísticas históricas de España: siglos XIX y XX. Bilbao: Fundación BBVA, pp. 645-706.

FOGEL, Robert W. (1994): «Economic Growth, Population Theory, and Physiology: The Bearing of Long-Term Processes on the Making of Economic Policy». American Economic Review 84 (3), pp. 369-395.

HABER, S.; MAURER, N., y RAZO, A. (2003): The Politics of Properties Rights: Political Instability, Credible Commitments, and Economic Growth in Mexico, 1876-1929. Londres: Cambridge University Press.

Si el artículo incluye referencias a fuentes de archivo, éstas se relacionarán aparte y antes de la Bibliografía, bajo el título de «Fuentes».

b. Notas a pie de página. Todas las notas irán a pie de página, numeradas mediante caracteres arábigos, en formato superíndice y en orden creciente, siempre antes de un punto. En las notas no se incluirán las referencias bibliográficas completas, sino solamente su forma abreviada. Ejemplo: Cubel (2003: 322-325).

c. Citas. Las citas irán entrecomilladas y, cuando excedan de tres líneas, separadas del cuerpo principal del texto. En este último caso, irán sangradas y a espacio sencillo. Cualquier cambio introducido en la cita original deberá indicarse encerrándolo entre corchetes.

d. Figuras. Los cuadros, gráficos y mapas habrán de ser originales; llevarán un encabezamiento breve, irán numerados por orden de aparición en el texto, y especificarán la fuente de la que proceden.

6. Adecuación de los artículos aceptados a las normas de edición. Los autores de los artículos aceptados, en cualquier caso, deberán enviar una nueva versión adaptada al formulario de «normas de edición RHE-JILAEH» en un plazo nunca superior a los diez días.

7. Corrección de pruebas. Los autores de artículos aceptados para publicación podrán ser requeridos para la corrección de pruebas de imprenta, que habrán de ser devueltas en un plazo siempre inferior a los diez días. No se permitirá la introducción de cambios sustanciales en las pruebas, quedando éstos limitados a la corrección de errores con respecto a la versión aceptada.

8. Copyright. Es condición para la publicación que el autor o autores ceda(n) a la Revista de Historia Económica los derechos de reproducción. Si se producen peticiones de terceros para reproducir o traducir artículos o partes de los mismos, la decisión corresponderá al Consejo Editorial.

9. Aviso. Cualquier incumplimiento de las presentes Instrucciones constituirá motivo para el rechazo del original remitido y, como mínimo, será causa de retraso en su proceso. 


\section{SUBMISSON INFORMATION}

1. Topics of interest. The Revista de Historia Económica. Journal of Iberian and Latin American Economic History publishes original research papers on economic history, economic thought and all those areas of economics concerned with longterm analysis. The geographical area addressed in these papers should preferably cover Spanish and Portuguese speaking countries and wider areas including any of these countries. Papers should be original and should be neither published nor be under consideration for publication elsewhere.

2. Evaluation process and publication times. The Editors will be rigorous and transparent in the Evaluation Process from the initial receipt to the final acceptance of the manuscript (See Review Process in Web page). In addition reasonable expeditious between receipt of the final manuscript, incorporating all required revision for acceptance, and the actual publication, is likely to be two or three issues (ie., eight month to one year).

3. Submission of manuscripts. The manuscripts may be sent in Spanish, English or Portuguese and should preferably be sent by e-mail (rhe-jilaeh@uc3m.es) or, if not, a paper copy (one) together with a Microsoft Word or PDF file on a disk or CD-ROM to the address given below. The graphs, tables and maps which can not be included in the file may be submitted in an additional Microsoft Excel file. The mailing address for submission of manuscripts is:

Prof. Antonio Tena (antonio.tena@uc3m.es).

Departamento de Historia Económica.

Universidad Carlos III de Madrid.

C/ Madrid, 126.

E-28903 Getafe (España).

RHE-JILAEH will acknowledge receipt of all manuscripts within 10 days of reception.

4. Format of submission. Manuscripts are to be submitted in double-spaced Times New Roman point 12 format. The text length should not exceed 30 pages $(10,000$ to 12,000 words), including graphs, tables, footnotes and references. The first page of the paper should include the title, name of author(s), affiliation, full address, e-mail and telephone number. Abstracts in Spanish and English of about 120 words, three to five keywords and JEL classification should be included on a second page. The rest of the manuscript must not include further references to the author(s) or any other mention which may reveal their identity (including references made in footnotes) in order to ensure the anonymous double-blind refereeing process. The structure of papers should be: text with footnotes, followed by appendices, and references (the latter single-spaced). When possible, graphs, tables and maps should be included on the corresponding text page, using the same font and a similar letter size as used in the text. If this is not possible, they may be included at the end of the manuscript or in a separate file. All pages should be numbered. Notes, Surveys and Speculations, Comments and Review of periodical literature should not be more than 10 pages $(3,300-4,000$ words) in length.

\section{Editing guidelianes:}

a. References. Bibliographical references should be listed by surname of author (in capital letters) in alphabetical order under a separate heading at the end of the manuscript. If more than one text by the same author(s) is cited for a particular year, then the works should be distinguished by a letter, e.g. Clark 
(2004a) and Clark (2004b). References are limited to the works cited in the manuscript. The following examples show the format to be applied to references:

MARTÍN ACEÑA, P., y PONS, M. ${ }^{a}$ A. (2005): «El sistema monetario y financiero", in A. Carreras and X. Tafunell (coords.), Estadísticas históricas de España: siglos XIX y XX. Bilbao: Fundación BBVA, pp. 645-706.

FOGEL, Robert W. (1994): «Economic Growth, Population Theory and Physiology: The Bearing of Long-Term Processes on the Making of Economic Policy». American Economic Review 84 (3), pp. 369-395.

HABER, S.; MAURER, N., y RAZO, A. (2003): The Politics of Property Rights: Political Instability, Credible Commitments, and Economic Growth in Mexico, 1876-1929. London: Cambridge University Press.

If the paper includes references to archives, statistics or documentary sources, these should be listed under an additional 'Sources' heading.

b. Footnotes. All notes are to be included as footnotes and numbered in ascending order of appearance in Arabic numbers as superscript before the full stop at the end of the sentence. Complete bibliographical references should not be included in the notes but rather in an abbreviated form, i.e. Cubel (2003: 322-325).

c. Quotations. Literal quotations should be limited and separated from the rest of the text if they exceed three lines. In this case they will be single-spaced and indented. All other quotations may appear in the text and should be clearly identified by quotation marks. Any change(s) made to the original quotation will be indicated by square brackets.

d. Figures. Tables, graphs, and maps should be original. They will include a short title, should be numbered in order of appearance and include the corresponding sources.

6. Upon acceptance of an article. Authors will be asked to resubmit a new version applying the more detailed RHE-JILAEH publication norms.

7. Galley proofs. Once the manuscript has been finally accepted for publication, the author(s) may receive galley proofs which are to be returned within 72 hours. Substantial changes to these proofs are not allowed and changes should be limited to lay-out corrections of the accepted manuscript.

8. Copyright. It is a condition of publication that the author(s) assign(s) copyright of their articles to the Revista de Historia Económica. Journal of Iberian and Latin American Economic History. Requests from third parties to reproduce or translate parts or the whole of articles will be considered by the editorial board.

9. Caveat. Any failure to comply with these guidelines may be considered a reason for rejection of the manuscript submitted or occasion a substantial delay in its processing. 


\section{EL TRIMESTRE ç ECONOMICO Je}

COMITE DICTAMINADOR: Enricue Casares Gi (UAM-A) Gonzalo Castañeda (UDLA-P) Sara Castelance (Banco de México), Gerardo Esquvel (Colmex), Lorenza Martinez (rTaM), Juan Carios Moreno Brid (CEPAL), Antonio Noriega Muro (Universidad de Guanajuato), Martín Puchet Anyul (UNAM), Graciela Te. neel (UA, CONSEJO EDITORLAL: Edmar L. Bache, Gerardo Bueno, Ennique Candenes, Arturo Femández, Ricardo Ffrench-Davis, Errique Flarescano, Roberto Frenikel, Kevin B. Grier, Ricardo Hausmann, Nejandro Hernendez, Albert O. Hirschman, Hugo A Hoperhayn, David loarra, Felipe Larrain, Francisco Lapes, Guilermo Maldanado, Rodolfo Manueli, José A Ocampo, Jaseph Ramos, Luis Angel Rojo Duque, Gert Rosenthal, Francisco Sagasi, Jaime Jose Serra, Jesís Silva Herzog Flores, Osvaldo Sunkel, Carlos Tello, Sweder van Winjerger.

Director. Fausto Hemández Trilo

Secretario de Redacciónc Guilemo Escalante A

\begin{tabular}{lll}
\hline Vol. LXXIV (1) México, Enero-Marzo de 2007 & NL̈m. 293
\end{tabular}

Perspectiva Econónica

Claudio González-Vega Las mierofinanzas en la profundización dél sistems financiey Marcelo Villafani-lbarnegaray no. El caso de Bolvis

ARTICULOS

Darcy Fuenzalida, Samuel Evaíuación de proyectos en mercados de capitales incomMongrut y Mauricio Nash pietos

Dante Contreras y Rodrigo Herrera Refuerzo escolar para nifios pobres: ¿Funciona?

Carlos Maquieira V., Sergio Determinantes de la estructura de fivianciación. Evidencie

Olavarrieta S. y Pablo Zutta G. empirica para Chie

Fermando Mesa Exporfaciones y poridicss comerciales áptimss para la indus. y Juan Ricardo Perilla tria textil $y$ de confecciones. Casos de Colombia y Méxóco, 1990-2002

Carlos A. Rodriguez Efectos de la tass de las fondos federaies de fos Estados Uniy Wilfredo Toledo dos en uns economis pequeria, abierta y dolanizada. El caso de Puerto Rico

NOTAS Y COMENTARIOS

Jorge A. Cháwez Presa Roforma presupusestaria para una Estado modistributivo

Comentafaos abuograficos, Ignacio Perrotini Hemández: Ricardo Ffrench-Davis, Reformas para América Latina: después del fundamentalemo molibaral, Buenos Aires, Siglo XXI Editores-CEPA. Argentina, 2005, $328 \mathrm{pp}$

EL. Trimestre Económco aparece en los meses de enero, abril, julio y octubre. La suscripción en Méxi$\infty$ cuesta $\$ 275.00$. Número suelto $\$ 90.00$.

Precios para otros paises (dotares)

$\begin{array}{lcc}\text { Centroamérica y el Caribe } & \text { Suscripciones } & \text { Mimero sverto } \\ \text { Sudamerica y Esparia } & 70.00 & 20.00 \\ \text { Canads, Estacos Unidos y resto del mundo } & 90.00 & 30.00 \\ & 120.00 & 33.00\end{array}$

Fondo de Culura Económica, Carretera Picacho Ajusco 227, Col. Bosques del Pectregal, 14200 Mexico,

Distrito Feceral. Suscripciones y anuncios: vel: 52274671 , fax: 54491827 / 52274649 ,

scriora Ima Barrón. Corteo electrónico: trimestre@fondodeculturacoonomica com

Página del Fondo de Cultura Econónics en Internet: hätplihwww fondodeculturasconomica.com 


\section{INVESTIGACIONES \\ 2007 * INVIERNO * NÚMERO 7 de HISTORIA ECONÓMICA}

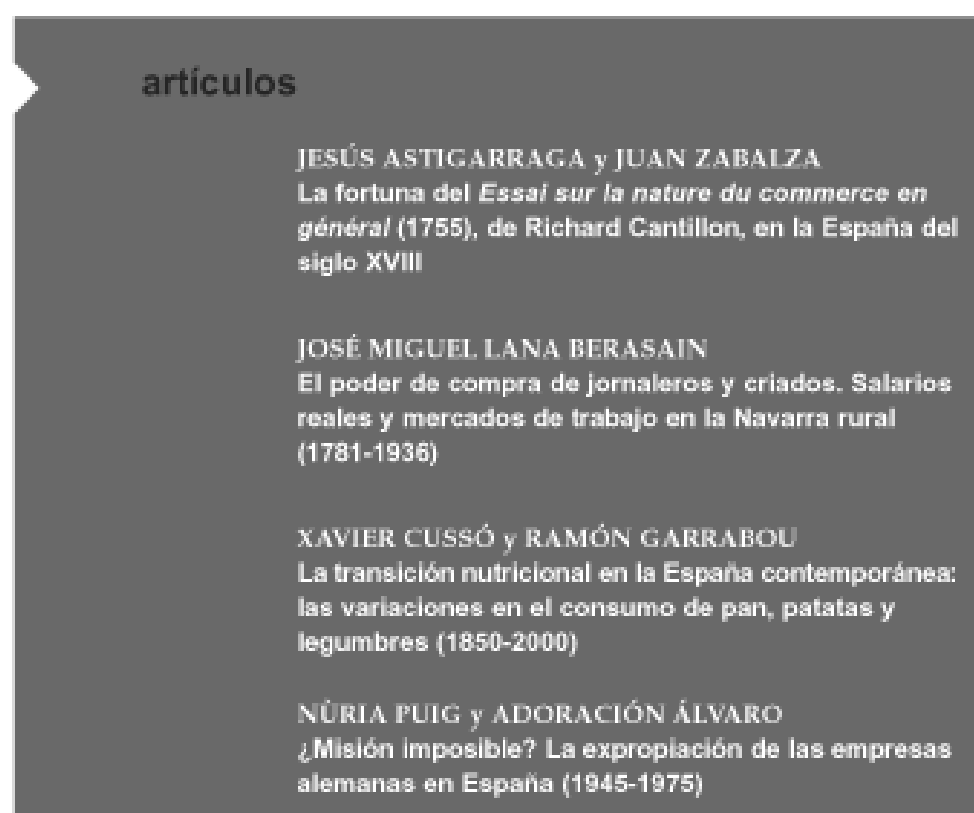

panoramas

ENRIQUE IBÁNEZ ROJO

El debate sobre la "Gran Divergencia" $y$ las bases institucionales del desarrollo económico 


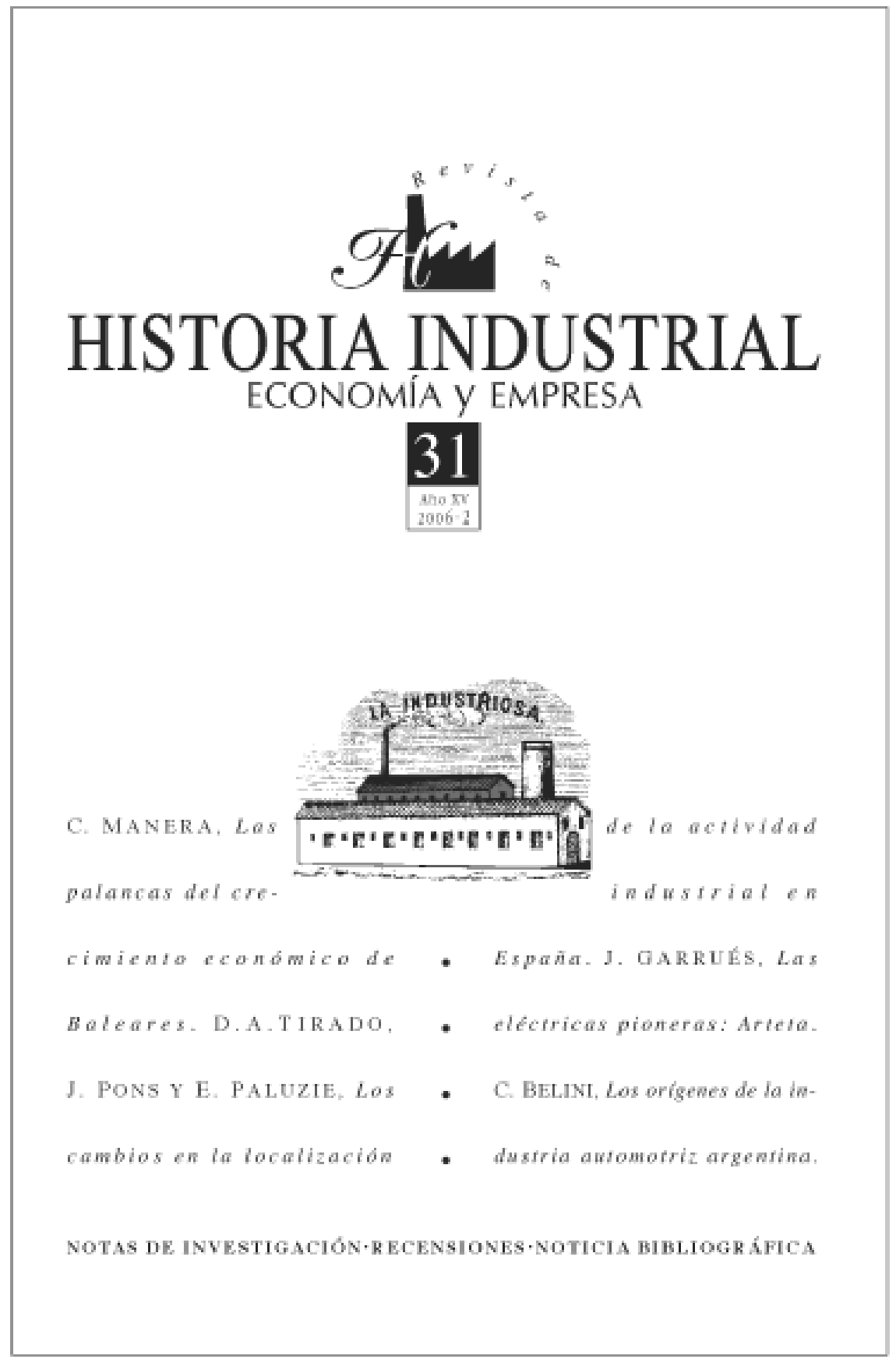




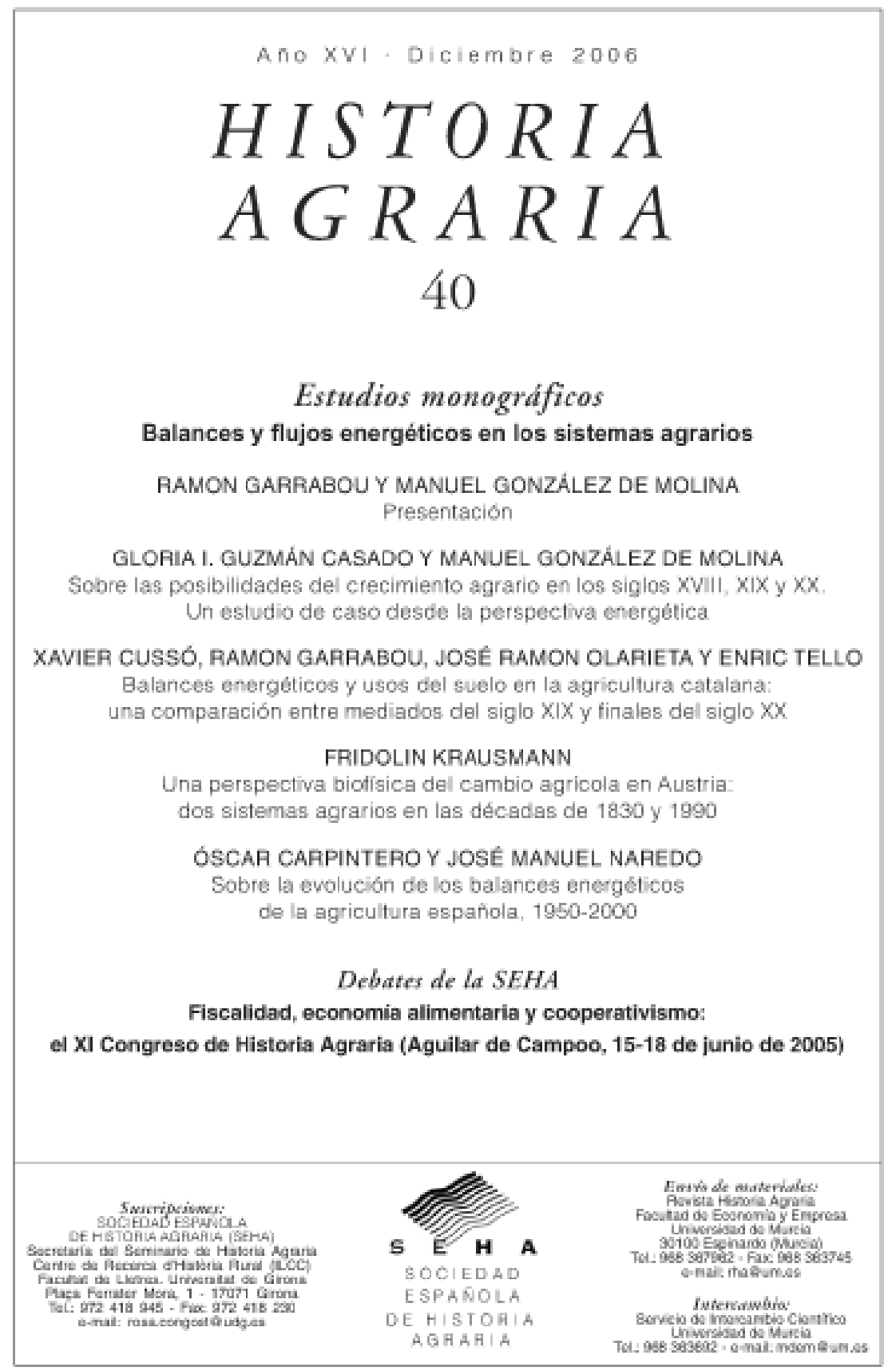




\section{DOCUMENTOS DE TRABAJO \\ de la \\ ASOCIACIÓN ESPAÑOLA DE HISTORIA ECONÓMICA}

\section{Últimos textos publicados}

DT-AEHE 0601 DÍAZ MORLẢN, Pablo: El mercado de función empresarial

DT-AEHE 0602 LLOPIS, Enrique y GONZÁLEZ MARISCAL, Manuel: La tasa de urbanización en España a finales del siglo XVIII: el problema de las agrociudades

DT-AEHE 0603 IRIARTE, Iñaki y AYUDA, $\mathrm{M}^{\mathrm{n}}$ Isabel: Una estimación del consumo de madera en España entre 1860 y 1935

DT-AEHE 0604 LANA, José M. Commons for Sale. Economic and Institutional Change in Nineteenth Century Northern Spain

DT-AEHE 0605 ZAPATA BLANCO, Santiago: Series de deflactores corcheros desde 1900

DT-AEHE 0606 PINILLA, Vicente y AYUDA, M" Isabel: "Horn of Plenty" Revisited: the Globalization of Mediterranean Horticulture and the Economic Development of Spain, 1850-1935

DT-AEHE 0607 ASTIGARRAGA, Jesús y ZABALZA, Juan: La Economia en los diccionarios y las enciclopedias del siglo XVIII en España

http://www achenet 